\title{
JARINGAN INFORMASI DAN KOMUNIKASI ORGANISASI VOC DI SULAWESI (MAKASAR) 1735-1737: \\ Studi Kasus Arsip Overgekomen Brieven en Papieren (OBP) sebagai Penghubung Vital Komunikasi VOC
}

\section{$\begin{array}{llllllll}\text { I } & \mathbf{N} & \mathbf{T} & \mathbf{I} & \mathbf{S} & \mathbf{A} & \mathbf{R} & \mathbf{I}\end{array}$}

Penelitian ini bertujuan untuk menganalisis jaringan informasi dan komunikasi organisasi dagang terbesar di abad 17 dan 18, Vereenigde Oost-Indische Compagnie (VOC), khususnya organisasi VOC di Sulawesi (Makasar). Arsip yang diteliti adalah khazanah arsip VOC yang terdapat di Nationaal Archief(NA) Belanda, yaitu arsip Overgekomen Brieven en Papieren (OBP) nomor 2381. Metode yang digunakan adalah deskriptif analisis dengan menggunakan sumber primer arsip OBP dan sumber sekunder literatur yang berkaitan dengan jaringan dan VOC. Hasil penelitian ini menunjukan bahwa arsip OBP memiliki struktur yang dapat menggambarkan sistem komunikasi VOC, dan topik yang paling banyak didiskusikan dalam korespondensi antara organisasi VOC di Makasar dengan pos-pos terluar adalah mengenai bajak laut dan perang.

\section{$\begin{array}{llllllll}A & B & S & T & R & A & C & T\end{array}$}

This research aims to examine how the networks, information, and communication wtihin the VOC organization, especially in Celebes (Makasar) work. Archives "Overgekomen Brieven en Papieren" number 2381 is the primary source for this research. This research uses descriptive-analysys method by using primary sources and secondary sources to be investigated. This research shows that $O B P$ has archival structure that can describe how the information and communication within VOC organization works. During 1735-37, the information that were mostly discussed were about piracy and war.
P E N U L I S

Jajang Nurjaman

Arsiparis

Arsip Nasional Republik Indonesia jajang.nurjaman@umail.leidenuniv.nl

KATA KUN C I

VOC, OBP, arsip, informasi, jaringan

KE Y WORDS

VOC, $O B P$, archives, information, network 


\section{PENGANTAR}

\section{Latar Belakang Masalah}

Ekspansi pelayar Belanda dan para pedagangnya telah lama dimulai sejak akhir abad ke-17. Ekspedisi pertama yamg lebih dulu terjadi adalah pada saat Cornelis de Houtman dan Gerrit van Beuningen mengunjungi Banten dan kemudian ke Maluku. Ekspedisi pertama ini didanai oleh compagnie van verre, nama yang digunakan sebelum Vereenigde OostIndische Compagnie (VOC) berdiri. Compagnie van verre awal mulanya terdiri atas sembilan pedagang yang berlokasi di Amsterdam. Mereka memiliki modal yang cukup besar untuk diinvestasikan ke perusahaan tersebut. Namun, dana yang besar masih dibutuhkan dari pedagang lain untuk mendirikan sebuah perusahaan. Maka, participant atau pemegang saham lainnya kemudian bergabung, dan menjadi inisiator dari pendirian perusahaan. Mereka inilah para direktur perusahaan tersebut (Jacob, Els 1991: 10-12).

De Houtman dan van Beuningen telah membuka gerbang ke timur. Mereka suskses menemukan rute terbaik untuk berlayar ke timur. Rute ini sebetulnya sudah ditemukan sebelumnya oleh para pelaut dan pedagang Portugis. Pelayaran pertama kali ke timur tidak membawa untung yang banyak, tetapi telah membuka ide bahwa pelayaran ke Asia adalah bukan hal yang tidak mungkin. Arus kapal yang berlayar setelah pelayaran pertama ini meningkat. Dari tahun 1595 hingga 1601, jumlah kapal yang berlayar mencapai hingga 65 kapal. Pada masa itu, perjalanan ke Asia bukanlah hal yang mudah karena tingginya eskalitas bencana di laut dan juga ancaman dari bajak laut. Belum lagi banyak penyakit tropis yang menghantui para awak kapal. Periode pelayaran antara tahun 1595 dan 1601 disebut sebagai periode "gold rush". Kapal-kapal berangkat dari tempat berbeda di Belanda pada waktu yang sama. Banyak kapal yang pulang membawa untung, banyak pula yang tidak membawa apa-apa, bahkan tidak kembali. Kabar suksesnya pelayaran tersebut cepat menyebar di kalangan pengusaha dan menyebabkan persaingan. Persaingan tersebut mengakibatkan naiknya harga beli rempah, sementara harga jual rempah di Belanda mengalami penurunan karena jumlah rempah yang beredar sangat banyak. Demi mencegah lebih banyak lagi persaingan, Staten Generaal (Pemerintah Tertinggi di Belanda) mengajak perusahaanperusahaan tersebut untuk membentuk sebuah perusahaan tunggal. Mereka setuju membentuk VOC yang 
memiliki hak monopoli perdagangan dan pelayaran Belanda di Asia (Jacobs, E.M 1991: 12).

Setelah VOC terbentuk, dimulailah pengiriman kapal lebih banyak lagi ke Asia. Hak octrooi yang didapat VOC membuat VOC menjadi pemain tunggal di Asia. Hak tersebut juga memungkinkan VOC untuk mendeklarasikan perang atas nama pemerintahan tertinggi di Belanda. VOC juga memiliki hak untuk mengadakan perjanjian dengan para penguasa lokal di Asia. Hak-hak tadi memungkinkan VOC untuk mendirikan pos-pos perdagangan, membangun benteng-benteng, membentuk pasukan, serta menunjuk pegawai-pegawainya sebagai administrator di Asia (Jacobs, E.M 1991: 12).

Salah satu hak octrooi VOC adalah hak untuk bernegosiasi dengan penguasa lokal. VOC dengan cerdik melakukan banyak negosiasi perdagangan dengan para penguasa lokal. Terkadang, negosiasi antara keduanya tidak tercapai, dan mengakibatkan perang. Gaastra berpendapat bahwa serangan serdadu VOC pada mulanya tidak bertujuan untuk menyerang masyarakat lokal. Mereka awalnya ingin menyerang pasukan Portugal yang merupakan pesaing dagang di Asia, namun pada akhirnya serdadu VOC menyerang masyarakat lokal juga. Masyarakat lokal menganggap VOC datang untuk menggantikan Portugal sebagai penjajah baru. Selain itu, VOC juga dianggap banyak mengingkari perjanjian-perjanjian dengan penguasa lokal.

Sekitar tahun 1608 dan 1609, seorang mantan direktur VOC dari Rotterdam, Cornelis Matelieff de Jonge memberikan pernyataan tentang pembangunan sebuah empire. Dia mencontohkan Portugal yang memiliki satu tempat permanen sebagai pusat administratif di Goa. Selain sebagai pusat administratif, Goa juga berfungsi sebagai tempat tinggal Dewan dan Gubernur Jenderal. Ketika itu, de Jonge mengusulkan Jacatra sebagai "ibukota" VOC di Asia. Hal ini menjadi kenyataan ketika Jan Pieterszoon Coen menaklukan Jacatra, yang kemudian diberi nama Batavia oleh petinggi di Belanda. Batavia lalu menjadi pusat VOC di Asia(Gaastra, F.S. 2012:39).

Ekspansi VOC telah menyebabkan juga pertumbuhan kantor-kantor VOC lainnya di Asia. Kantor-kantor tersebut semua berada di bawah otoritas Batavia, maka mereka melaporkan kejadiankejadian, kondisi perdagangan, dan hal lainnya kepada pegawai-pegawai 
VOC atau petinggi-petinggi VOC di Batavia. Dari kewajiban melaporkan ini, maka terciptalah korespondensi antara VOC di Batavia dengan VOC di kantor-kantor lain di luar Batavia. Korespondensi ini biasanya meliputi pembahasan masalah ekonomi, politik, dan kehidupan sosial. Melalui tulisan ini, penulis melakukan pembahasan mengenai pertukaran informasi apa yang terjadi dan dari siapa kepada siapa (aktor di balik pertukaran informasi). Pertukaran informasi mengenai keadaan kehidupan lokal tidak hanya terjadi antara otoritas VOC di Hindia Timur, namun juga dikirim ke Tuan-Tuan XVII di Belanda (pemerintahan tertinggi di Belanda). Pemerintahan Agung di Batavia mengumpulkan informasi dari kantor-kantor di luar Batavia dan mengirimkannya kembali ke pengurus VOC di Belanda. Salah satu kantor yang cukup aktif dan penting serta memiliki gubernur adalah Makassar. Penulis akan menganalisis bagaimana sistem informasi dan jaringan VOC bekerja di level lokal, yaitu di daerah Makassar.

\section{Rumusan Masalah}

Komunikasi dan korespondensi antara Tuan-Tuan XVII di Amsterdam dan Pemerintahan Agung di Batavia menjadi sangat penting karena Tuan-
Tuan XVII sangat bergantung pada ketersediaan informasi dari Pemerintahan Agung dan sebaliknya. Informasi tersebut diangkut dengan kapal dari Batavia dan tersimpan di dalam berbagai jenis dokumen, misalnya duplikat prosiding Dewan dan Gubernur Jenderal, duplikat suratsurat keluar atau dokumen-dokumen Dewan dan Gubernur Jenderal, dan surat-surat serta dokumen yang diterima dari kantor-kantor VOC di Asia. Dokumen-dokumen tersebut dikenal dengan nama Overgekomen Brieven en Papieren (OBP). Artikel ini akan menginvestigasi arus informasi yang terjadi antara kantor VOC di Asia, khususnya Makasar, dengan Batavia dan Amsterdam. Permasalahan yang dikaji dalam penelitian ini adalah:

1. Apakah fungsi OBP dalam sistem komunikasi antara Tuan-Tuan XVII dan Pemerintahan Agung?

2. Siapa yang terlibat dalam penyusunan informasi hingga menjadi OBP?

3. Informasi apa yang terkandung di dalam OBP yang diterima kantor VOC Amsterdam?

Pola komunikasi antara Pemerintahan Agung dan Tuan-Tuan XVII juga akan diinvestigasi. Fokus penelitian ini terletak pada periode tahun 17351737. Periode tersebut adalah periode 
tersibuk kapal yang kembali ke Belanda. Sulawesi dengan Makasar sebagai pusat administrasinya dipilih sebagai lokus penelitian karena merupakan kantor VOC teraktif di timur Nusantara pada masa tersebut.

\section{Tujuan Penelitian}

Penelitian ini bertujuan untuk menganalisis arsip OBP guna mendapatkan gambaran mengenai sistem komunikasi dan jaringan informasi VOC di Sulawesi periode tahun 1735-1737. Penelitian dilakukan dengan menganalisis beberapa bundel arsip OBP. Secara ringkas, penelitian ini dimaksudkan untuk:

1. Menggali informasi mengenai sistem komunikasi organisasi VOC di Sulawesi;

2. Mengetahui aktor-aktor dalam pertukaran informasi organisasi VOC di Sulawesi;

3. Mengetahui fungsi OBP secara umum dalam jaringan komunikasi di tubuh organisasi VOC.

\section{Metode Penelitian}

Untuk menjawab permasalahan penelitian, metode yang digunakan adalah deskriptif analisis. Penelitian ini fokus pada analisis sumber primer. Proses analisis dimulai dengan membaca dan menelaah literatur mengenai organisasi VOC dan jaringan informasi VOC. Buku Geschiedenis van VOC karangan Femme Gaastra digunakan untuk mengetahui secara menyeluruh bagaimana struktur oganisasi VOC dan fungsinya. Untuk mengetahui teori mengenai jaringan dan koneksi, buku Kerry Ward dan Zoë Laidlaw menjadi sumber referensi. Untuk meneliti sumber primer, yaitu arsip OBP yang berada di Nationaal Archief (NA), Arsip Nasional Belanda, penulis pertama-tama menelaah sebuah terbitan naskah sumber berjudul Generale missiven van gouverneursgeneraal en raden aan Heren XVII der Verenigde Oostindische Compagnie karangan J. Van Goor. Setelah menelaah buku tersebut, arsip OBP diteliti. OBP yang digunakan adalah OBP yang diterima oleh kamar Amsterdam dan dikirim dari Batavia. Amsterdam di abad 17 dan 18 bertanggungjawab mengurusi setengah dari pekerjaan VOC.

Data yang dikumpulkan berasal dari inventaris arsip VOC di Arsip Nasional Belanda. Dari inventaris, ada 123 bundel arsip OBP yang dikirim dari Batavia ke Amsterdam. Setiap bundel memiliki kurang lebih seribu halaman arsip. Mengingat jumlah yang sangat banyak, maka hanya bundel arsip 
nomor 2381 menjadi korpus data penelitian. Bundel ini dipilih karena mengandung informasi tentang Makasar. Selain itu, bundel tersebut memiliki sekitar 2000 halaman, dan cukup representatif untuk menjawab permasalahan dalam penelitian ini. Bundel nomor 2381 pertama-tama dilihat daftar isinya, atau disebut register. Register dianalisis untuk mendapat gambaran mengenai struktur arsip. Setelah mengumpulkan informasi mengenai jenis dokumen apa saja yang terdapat di bundel nomor 2381, beberapa surat yang ada di dalam arsip dianalisis lebih lanjut untuk menjadi sampel penelitian ini. Totalnya ada 329 surat yang dianalisis. Surat-surat yang telah dianalisis digunakan untuk menjawab pertanyaan penelitian. Analisis dilakukan terhadap proses pembukaan surat hingga hal-hal lain seperti pengirim dan penerima surat.

\section{Kerangka Pemikiran}

Organisasi VOC

VOC didirikan tahun 1602. Perusahaan ini merupakan gabungan dari enam kamar di Republik (Belanda pada saat itu), yaitu kamar dagang Amsterdam, Zeeland, Delft, Rotterdam, Enkhuizen dan Hoorn. Masing-masing kamar dagang memiliki direktur (bewindhebber) dan juga gudang (pakhuis). Amsterdam memiliki 20 direktur, Zeeland memiliki 12, Delft, Rotterdam, Enkhuizen dan Hoorn masing-masing memiliki 7 direktur. Hierarki paling atas dipegang oleh Tuan-Tuan XVII yang diisi oleh 17 orang yang mewakili kamar-kamar dagang. Amsterdam memiliki 8 perwakilan, Zeeland 4 perwakilan dan yang lain masing-masing memiliki satu perwakilan. Perwakilan ke-17 berasal dari Zeeland atau dari kamar dagang yang kecil. Jadi, Amsterdam paling banyak memiliki perwakilan di TuanTuan XVII. Berdasarkan octrooi, Tuan-Tuan XVII harus mengadakan rapat di Amsterdam selama enam tahun dan kemudian dua tahun di Zeeland.

Tuan-Tuan XVII biasanya mengadakan rapat tiga kali setahun. Namun, pada praktinya, mereka sering mengadakan rapat dua kali setahun. Hal ini menjadi kebiasaan setelah tahun 1751. Komisi-komisi yang telibat dalam rapat Tuan-Tuan XVII adalah:

1. Komisi untuk menyusun laporan keuangan tahunan;

2. Komisi untuk menghadiri dan mengawasi lelang kamar-kamar;

3. Kosmisi yang membaca korespondensi dan dokumen yang diterima dari Asia dan kemudian 
menyusun draf jawaban untuk Asia. Komisi ini, yang terdiri atas 4 direktur dari Amsterdam, 2 dari Zeeland dan masing-masing 1 dari kamar-kamar yang lebih kecil, bertemu di Den Haag, dikenal dengan nama Haags Besogne;

4. Komisi Rahasia, secrete commissie yang bertugas ketika masa parang.

Musim juga sangat memberikan dampak pada rapat-rapat Tuan-Tuan XVII karena subjek rapat tergantung pada musim dagang dan musim berlayar (waktu tiba kapal). Musim gugur dapat dianggap sebagai musin pertama dari siklus rapat. Dokumen yang datang disusun berdasarkan kembalinya kapal dari Asia, sekitar akhir Agustus. Rapat tersebut mengambil keputusan terkait aktivitas VOC di Asia. Rapat berikutnya diadakan pada awal musim semi, seringnya pada bulan Februari atau bulan Maret. Keputusan yang dibuat selama sesi ini adalah mengenai lelang musim semi yang biasanya VOC hanya menawarkan rempah untuk dijual. Rapat juga membahas kemajuan pengembangan kapalkapal. Rapat ketiga Tuan-Tuan XVII biasanya diadakan pada musim panas, biasanya pada bulan Juli, namun kadang-kadang pada bulan Agustus. Rapat ini mengambil keputusan tentang kuantitas barang berharga yang dikirim melalui kapal yang akan berlayar bulan September (Balk dan Van Dijk, 2007: 19-26).

\section{Organisasi VOC di Asia}

VOC di Asia sifatnya unik karena keberadaan mereka berdasarkan hak octrooi. Direktur-direkturnya memutuskan untuk menempatkan pemimpin tertinggi di Asia. Maka, VOC membentuk Gubernur Jenderal dan Raad van Indië (Dewan Hindia). Keduanya membentuk suatu pemerintahan yang dinamakan Hoge Regering (Pemerintahan Agung). Lembaga ini menjadi pusat otoritas VOC di Asia dan berkedudukan di Batavia (sekarang Jakarta).

Anggota-anggota Dewan Hindia memiliki tugas membantu Gubernur Jenderal pada semua masalah seperti manajemen umum perdagangan, perang, pemerintahan, serta penegakkan keadilan di semua masalah publik dan kriminal. Masingmasing anggota memiliki tanggung jawab masing-masing dan harus melaporkan ke Pemerintahan Agung yang kemudian dilaporkan ke TuanTuan XVII (Balk dan Van Dijk, 2007: 19-26).

Batavia yang menjadi kedudukan Pemerintahan Agung, juga menjadi pusat administrasi dan tempat 
bertemunya kapal-kapal yang datang dari Belanda. Sebagai pusat administrasi, Batavia menerima banyak surat dari kantor-kantor VOC di Asia. Surat yang datang ke Batavia dilaporkan ke Tuan-Tuan XVII. Surat tersebut memuat informasi mengenai laporan kondisi di wilayah Asia, terutama masalah perang dan dagang. Surat-surat yang masuk kemudian didiskusikan oleh para konselor sebelum ditandatangani oleh Gubernur Jenderal dan Dewan Hindia. Surat-surat ini dikenal dengan nama generale missive. Pemerintahan Agung juga bertanggung jawab dalam mengumpulan laporan-laporan yang berisi kebutuhan uang, barang, dan juga pasukan. Laporan ini dapat bertambah atau berkurang tergantung dari pendapat mereka terhadap laporan tersebut. Laporan inilah yang kemudian dijadikan sebagai panduan Tuan-Tuan XVII dalam mengambil keputusan terkait dengan masalah yang ada. Laporan tersebut dikenal dengan nama generale eis.

Tidak semua kantor VOC melaporkan kondisinya ke Batavia terlebih dahulu. Kantor di Sri Lanka misalnya, langsung melaporkan ke Tuan-Tuan XVII karena mereka memandang Sri Lanka sebagai tempat yang menguntungkan untuk berdagang kayu manis. Komoditas ini dapat dengan cepat merambah Eropa. Selain Sri Lanka, kantor VOC di Persia juga mengirimkan suratnya langsung ke Belanda melalui jalur darat via Levant. VOC membagi dua jenis kekuasaan untuk kantornya di Asia, yaitu gubernur dan direktur. Tempat yang sekaligus memiliki otoritas teritorial diperintah oleh seorang gubernur, sedangkan tempat yang dasarnya adalah kontrak diperintah oleh seorang direktur. Ada juga semacam commander in chief di Padang dan Malabar. Wilayah seperti Cirebon, Banjarmasin, dan Palembang, dipimpin oleh seorang opperhoofden (kepala senior) seperti Gubernur Jenderal. Mereka adalah orang nomor satu tetapi tidak dapat mengambil keputusan sendiri. Mereka harus berdiskusi dengan Dewan (Gaastra, F.S, 2012: 76).

\section{Organisasi VOC di Makasar}

Makasar menjadi kantor yang penting ketika VOC berhasil mengalahkan musuhnya, pedagang Eropa lainnya, dan kemudian mulai memonopoli perdagangan rempah di Sulawesi. Penguasa lokal di sana, Sultan Goa, meraih banyak keuntungan dari lalu lintas laut yang sibuk di dekat Kepulauan Maluku. Sultan menolak untuk menutup pelabuhannya untuk perdagangan rempah. Namun, VOC 
memperlakukan secara khusus satu dari penguasa lokal di sana, Arung Palakka. Tahun 1669, Makasar takluk ke tangan Belanda dan VOC mulai membangun kekuasaannya di sana dengan mendirikan Benteng Rotterdam (Jacobs, E.M, 1991: 28). Setelah menaklukan Makasar, VOC mulai mengembangkan bisnisnya dengan memonopoli penjualan cengkeh di seputar Sulawesi. Benteng Rotterdam juga berfungsi sebagai benteng pelindung terhadap seranganserangan bumiputera. Menurut Jacobs, sekitar tahun 1700-an, gubernur meraup sukses dalam mengendalikan situasi di Makasar. Gubernur tidak mau campur tangan dengan konflik warga lokal selama mereka tidak mengganggu bisnis VOC.

Struktur VOC di Makasar sama seperti struktur VOC di Asia. Gaastra berpendapat bahwa Makasar memiliki struktur yang sama dengan struktur VOC di Batavia. Keduanya sama-sama memiliki gubernur dan dewan untuk mengambil keputusan di otoritasnya.

\section{Sistem Komunikasi VOC}

Jarak yang jauh antara Batavia dan A msterdam menyebabkan komunikasi berjalan sangat lambat. Sebuah kapal memerlukan waktu hampir sembilan bulan untuk berlayar dari Asia ke Belanda, dan sebaliknya. Kapal berlayar pada setiap Natal dan Paskah. Kapal-kapal tersebut akan tiba di Katulistiwa pada waktu yang pas. Sejak 1636, ada aturan bahwa setiap kapal yang berlayar di September atau Oktober akan tiba di Batavia tepat waktu. Kapal-kapal tersebut membawa pesan dan juga barang ke gudang di Cina dan Jepang. Maka, ada konsep tiga kapal, yaitu kapal karnaval, mengacu ke karnaval Amsterdam di bulan September, serta kapal Natal dan Paskah (Balk dan Van Dijk, 2007:24).

Kapal yang kembali ke Belanda tidak hanya membawa barang dari Asia, tetapi juga surat-surat dari Batavia. Surat-surat yang berasal dari kantor-kantor Asia ke Batavia dikumpulkan di Kastil Batavia. Sekretariat Umum membantu Pemerintahan Agung ketika rapat berlangsung. Ia menulis keputusankeputusan yang kemudian dibantu oleh para juru tulis (klerk). Mereka juga menyimpan dokumen-dokumen lain seperti laporan-laporan dari kantor-kantor, catatan harian aktivitas Pemerintahan Agung, dan juga membuat salinan untuk Tuan-Tuan XVII dan kamar dagang lain di Belanda. Jadi, Pemerintahan Agung mengambil keputusan berdasarkan 
surat-surat yang datang dari kantorkantor di Asia. Para sekretaris menulis dan menyalin keputusan-keputusan tersebut. Selanjutnya dokumen diangkut dengan kapal ke Belanda. Kapan yang kembali ke Belanda, berangkat pada bulan Desember atau Januari. Dokumen-dokumen inilah yang disebut dengan Overgekomen Brieven en Papieren (OBP) (Roelofsz, 1992: 44-45). Mengingat Tuan-Tuan XVII tidak memiliki tempat yang permanen untuk sekretariat, dokumen-dokumen tersebut juga disimpan di banyak tempat, seperti di kantor juru tulis atau di gereja-gereja. Dokumen tersebut selain dikirim lewat kapal, ada juga yang dikirim lewat jalur darat. Menurut Leupe, VOC di Gamron mengirim surat ke Belanda lewat jalur darat. Mereka memanfaatkan jaringannya untuk mengirim surat via Timur Tengah. Rutenya dari Basra ke Aleppo dan ke pelabuhan Iskenderun, sekitar Laut Tengah, dan lalu dikirim ke Venezia atau Livorno. Selanjutnya, surat akan tiba di Amsterdam via Marseille (Leupe, P.A, 1998: 77-90).

Amsterdam menjadi pusat komersil di Belanda karena Amsterdam adalah simpul beberapa hierarki regional perdagangan dan keuangan yang berbeda (Smith, W.D, 1984: 985-1005). Amsterdam juga berfungsi sebagai tempat perputaran informasi. Menurut Smith, sifat informasi sebagai komoditas dan sebagai produk sampingan dari sebuah proses perdagangan, telah tampak pada evolusi di Amsterdam menjadi pusat pertukaran informasi pada abad 17 di Eropa. Smith juga berujar bahwa fungsi informasi Amsterdam bersifat unik. Keunikan informasi inilah yang menggiring Amsterdam menjadi kontributor utama terhadap modernisasi ekonomi Eropa.

Batavia telah menjadi pusat administrasi VOC. Pemerintahan Agung berfungsi juga sebagai sekretariat umum untuk aktifitas VOC di Asia. Administrasi Batavia bahkan lebih aktif ketika pegawai-pegawai di sana harus membuat salinan keputusan (resolusi) yang telah dibuat oleh Pemerintahan Agung untuk kamar-kamar dagang VOC di Belanda. Konsekuensinya, pegawaipegawai tersebut akan sangat sibuk di bulan Desember dan Januari ketika kapal berangkat ke Belanda.

Kapal yang kembali ke Belanda juga membawa dokumen dari Batavia yang ingin dilaporkan ke direktur-direktur di Belanda. Mengingat waktu perjalanan yang cukup panjang ( 9 bulan), para pegawai VOC pun harus bekerja keras demi menjaga dokumen-dokumen dari 
Batavia sampai ke Belanda. Mereka juga menyalin dokumen-dokumen tersebut yang datang dari banyak kantor. Pekerjaan yang banyak tersebut membutuhkan juga pegawai yang banyak, dan juga waktu lembur yang banyak. Contohnya pada saat musim dingin, ketika kapal berangkat, jumlah dokumen yang akan dikirim juga meningkat. Sembilan puluh lima pegawai rata-rata direkrut oleh Sekretariat Umum pada abad 18. Tahun 1740 jumlah ini meningkat hingga 167 pegawai. Dokumen yang banyak mengandung informasi ini dikirim ke Belanda. Penciptaan dokumen yang melimpah ini karena
VOC selain berdagang, juga mengumpulkan semua informasi mengenai keadaan Asia, dan selanjutnya menjadi bahan laporan ke Tuan-Tuan XVII. Pegawai VOC di Amsterdam menyimpan dan mengelola informasi yang diterima secara sistematis. Sampai fase ini, VOC membentuk sebuah network, jaringan yang menghubungkan Batavia di Asia dan Amsterdam di Belanda via informasi yang mereka saling tukar.

Nico Vriend dalam tesisnya menjelaskan alur informasi VOC dalam kurun waktu 1737-1750 seperti tampak dalam peta berikut:

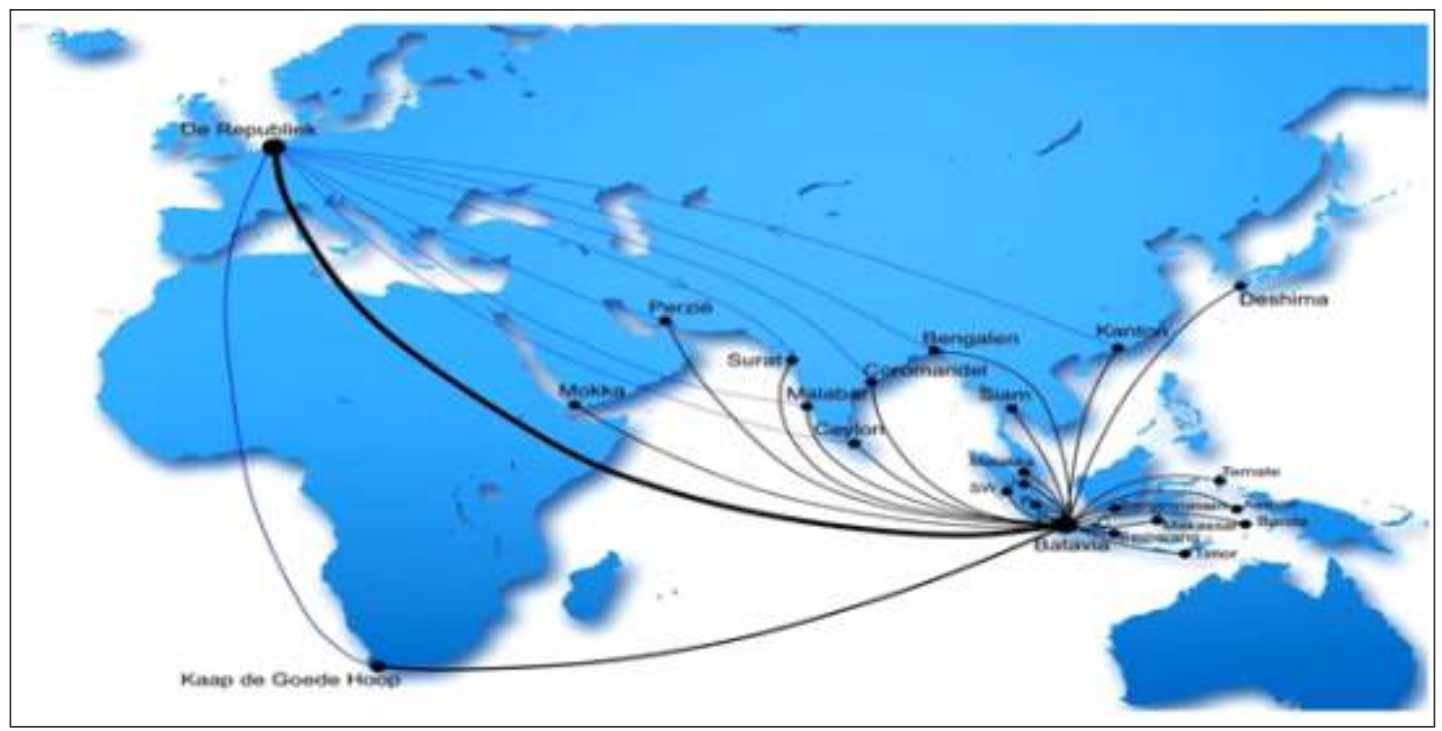

Gambar 1 Peta alur informasi VOC 1737-1750 (Vriend, 2011: 24) 
Peta di atas menunjukkan alur informasi antara Pemerintahan Agung di Batavia dan Tuan-Tuan XVII. Selanjutnya, peta ini juga menampilkan alur informasi antara Pemerintahan Agung dengan kantorkantor di luar Asia dan juga antara Tuan-Tuan XVII dan kantor-kantor tersebut. Garis yang tanpa panah, mengindikasikan alur komunikasi berlangsung dua arah (Vriend, 2011: 25). Peta tidak menunjukkan alur informasi di dalam suatu area khusus, misalnya alur informasi di dalam Makasar. Namun, peta ini memberikan pandangan umum bagaimana informasi bertukar di dalam organisasi VOC. Informasi dan sistem komunikasi VOC di dalam wilayah atau suatu kantor yang khusus, menarik untuk diteliti lebih lanjut. Artikel ini membahas lebih jauh mengenai intra-komunikasi VOC di Asia. Alur informasi dipandang lebih dalam untuk mendapatkan jenis informasi apa yang terjadi dan siapa aktor di belakang alur informasi tersebut.

\section{PEMBAHASAN}

\section{Overgekomen Brieven en Papieren (OBP)}

OBP adalah dokumen-dokumen dan surat-surat yang diterima kamarkamar VOC dari Asia. OBP menjadi spesial ketika Direktur-Direktur di Belanda pada tahun 1695 membangun ruangan khusus di Amsterdam untuk mengelola dokumen-dokumen tersebut. Penanganan khusus diperlukan karena dokumen yang datang terus meningkat dengan pesat (Roelofsz, M, 1991:45).

OBP memuat semua dokumen yang dikirim dari kantor-kantor di Asia kepada Tuan-Tuan XVII di Amsterdam. OBP adalah nama yang diberikan kepada semua dokumen yang diterima di kamar-kamar VOC di Belanda. Dalam periode tersebut, dua kamar, Amsterdam dan Zeeland, adalah kamar tersibuk yang menerima dokumen dari Asia. OBP sendiri merupakan bagian dari sebuah seri yang dinamakan ingekomen stukken uit Indië. Di seri ini terdapat lima kelompok besar seperti tampak pada tabel berikut: 


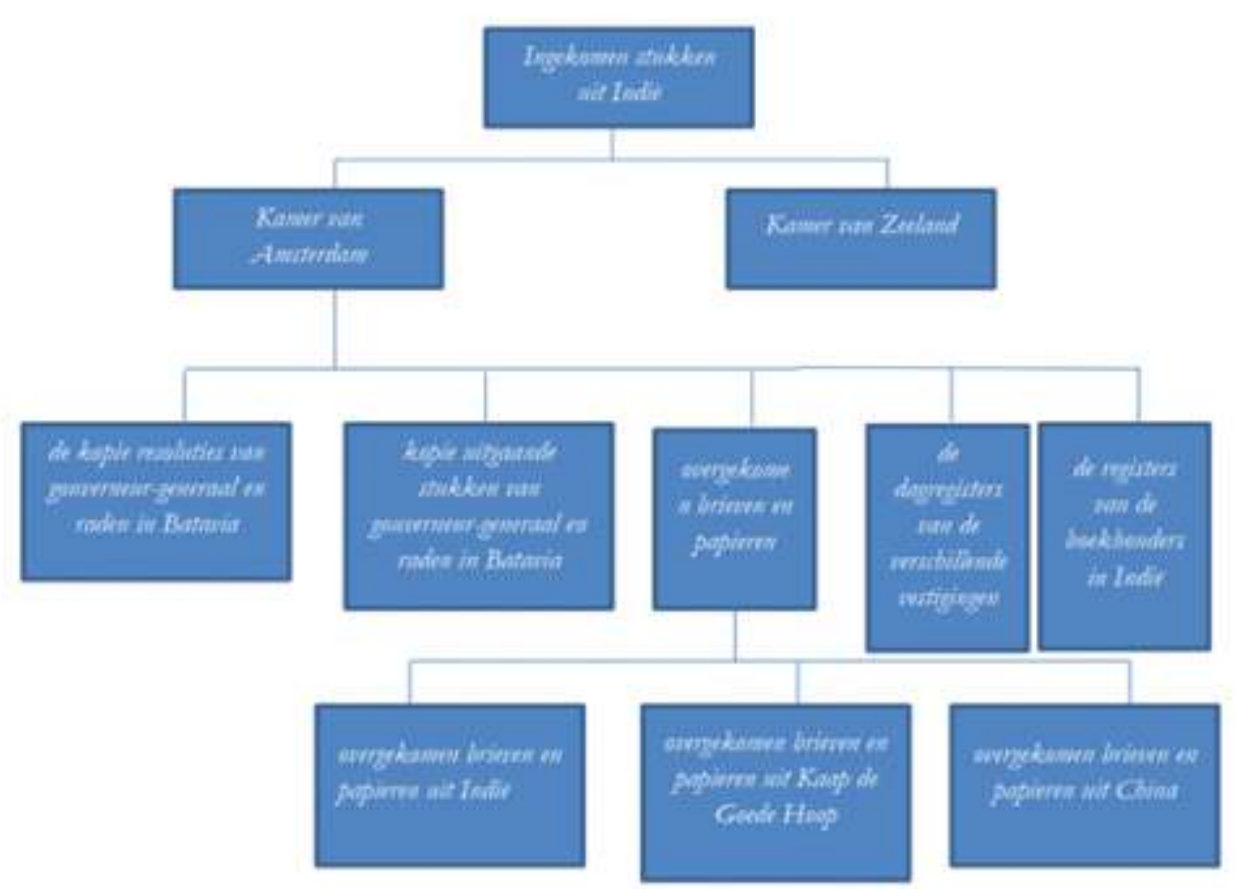

Bagan 1 Seri arsip Ingekomen Stukken uit Indie (Roelofsz, 1992)

OBP terdiri atas tiga kategori yang lebih spesifik, yaitu de overgekomen brieven en papieren uit Indië aan de Heren XVII en de Kamer Amsterdam (surat dan dokumen yang diterima dari Asia kepada Tuan-Tuan XVII dan Kamar Amsterdam), overgekomen brieven en papieren uit Kaap de Goede Hoop aan de Heren XVII en de Kamer Amsterdam (surat dan dokumen yang diterima dari Tanjung Harapan kepada Tuan-Tuan XVII dan Kamar Amsterdam), dan overgekomen brieven en papieren uit China aan de Heren XVII en de Kamer Amsterdam (surat dan dokumen yang diterima dari
Tanjung Harapan kepada Tuan-Tuan XVII dan Kamar Amsterdam), dan overgekomen brieven en papieren uit China aan de Heren XVII en de Kamer Amsterdam (surat dan dokumen yang diterima dari Cina kepada Tuan-Tuan XVII dan Kamar Amsterdam. Dari kelompok-kelompok tersebut, penelitian ini hanya akan berfokus pada OBP dari Asia untuk Tuan-Tuan XVII dan Kamar Amsterdam.

Pada gambar satu telah ditunjukkan bagaimana alur informasi di VOC bekerja. Gambar tersebut juga menunjukan alur informasi di Nusantara, yaitu informasi yang 
berasal dari kantor seperti Malaka, Jambi, Sumatra Barat, Palembang, Banten, Banjarmasin, Cirebon, Semarang, Makasar, Ternate, Ambon, dan Timor. Pegawai-pegawai VOC di Belanda mengirimkan dokumen ke pusat administrasi di Batavia sehingga informasi bertukar.

\section{Struktur OBP Bundel Nomor 381}

Struktur bundel arsip OBP nomor 2381 pada umumnya sama dengan struktur OBP lainnya. Sebelum bundel arsip tersebut diteliti, beberapa bundel arsip lain juga dilihat untuk mencari struktur arsipnya. Bundel lain yang diambil adalah nomor 1481, 1623, 1496 dan 2345. Bundel tersebut memiliki tahun arsip yang berbeda. Setelah melihat bundel-bundel tersebut, struktur arsip yang dimiliki mereka sama dengan struktur arsip bundel nomor 2381. Jadi, dapat diasumsikan jika semua bundel OBP memiliki struktur yang sama. Bundel arsip nomor 2381 seluruhnya berisi informasi mengenai Makasar. Jumlah halamannya mencapai 2000 halaman dan bahkan lebih. Jumlah halaman tidak dapat dihitung secara persis karena kondisi bundel yang sudah tidak bagus dan sulit dibaca dengan microreader.

Makasar sebagai pusat administrasi di wilayah Sulawesi menerima dokumen dari pos-pos VOC terdepan dan juga menerima dokumen dari kantor-kantor lain yang berkorespondensi dengan pemerintahan di Makasar. Struktur arsip OBP adalah sebagai berikut:

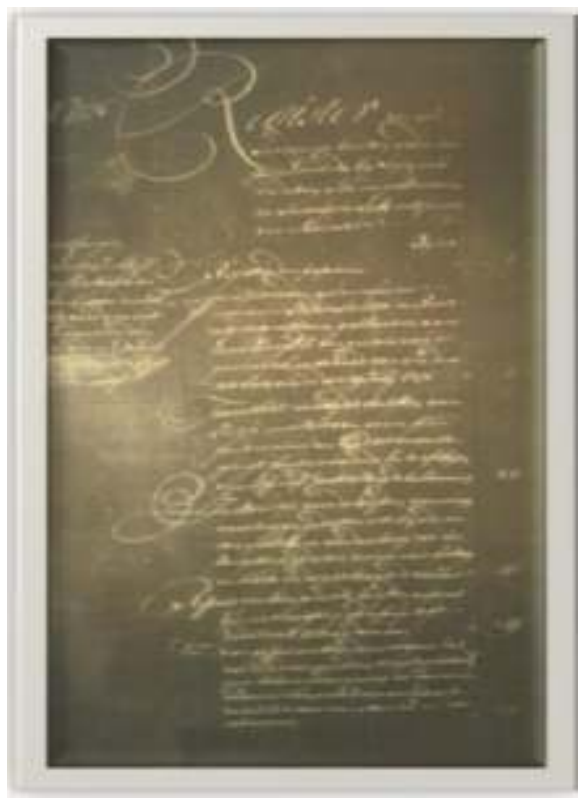

Gambar 2 Register arsip OBP nomor 2381, sumber: microfilm arsip NL-HaNA, VOC, 1.04.02, inv.nr. 2381 
Bundel ini disusun oleh pegawai VOC di Batavia. Hal ini bisa dilihat dari register pada halaman pertama bundel ini. Register menggambarkan dokumen berasal dari Makasar. Jika dihubungkan dengan organisasi VOC, maka diperoleh kesimpulan bahwa kantor di Makasar harus mengirimkan laporannya ke pusat administrasi di Batavia. Dari kepala surat tertulis:

"Register van alle soodanige brieven ende daar toegehoorende bijlagen als $n u$ dezen sijn ingeschreven en successivelijk ontfangen van Macasser"

Register dari semua suratsurat dan s e gala lampirannya sebagaimana diregistrasi di sini dan diterima secara periodik dari Makasar.

Kepala surat mengindikasikan dokumen diterima oleh pegawai VOC di Batavia dan tidak tiba dalam waktu bersamaan, namun secara periodik. Dokumen-dokumen tersebut diterima dalam satu bundel tebal, dan tidak dalam lembara-lembaran terpisah. Sebagai contoh di gambar 2, dokumen-dokumen tersebut diterima pada tanggal 21 Juli 1736:

"Ontfangen den 21 julij per de chialoup van den burger
Michiel de Vreede en uijt handen van den vendrigh Loijs (tidakterbaca)"

Diterima tanggal 21 Juli dengan perantara kapal Michiel de Vrede dan dari pegawai Loijs (tidak terbaca).

Contoh di atas menunjukkan bagaimana dokumen diterima di Batavia. Pemerintahan di Makasar mengirim dokumen-dokumen tersebut menggunakan kapal dan mereka juga mendelegasikan seorang pegawai untuk mengantar dokumendokumen tersebut. Dalam bundel 2381, dokumen-dokumen dan suratsurat diterima sebanyak empat kali, yaitu pada tanggal 21 Juli, 31 Agustus, 28 Oktober, dan 14 November 1736.Gambar 3 Struktur umum arsip OBP Selanjutnya, bundel 2381 memiliki komposisi yang konsisten. Bundel diawali dengan register yang disusun oleh pegawai di Batavia. Dalam bundel tersebut, ada juga register dari bundel-bundel yang lebih kecil yang registernya disusun oleh pegawai di Makasar. Bundel-bundel kecil ini berisi surat-surat untuk kantor administrasi VOC di Batavia. Kemudian generale missive (surat umum), instructie (instruksi), rapport (laporan), dan aankomend en afgaande brieven (surat masuk dan 
keluar) muncul berurutan. Pola ini muncul kembali dan diulang terus hingga register dari Makasar terlihat kembali. Diagram berikut menggambarkan struktur bundel 2381:

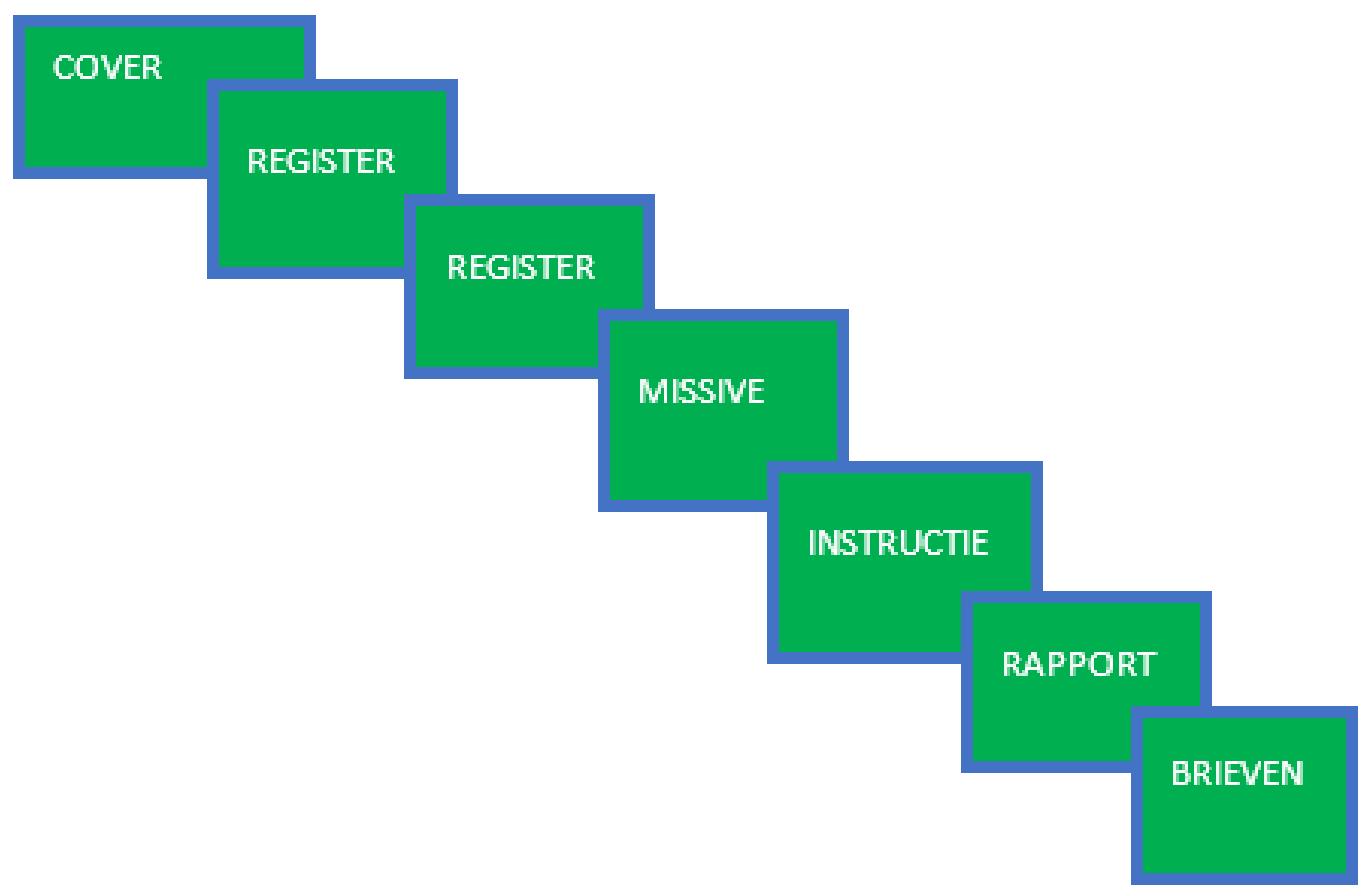

Gambar 3 Struktur umum arsip OBP

Dari diagram di atas dapat disimpulkan bahwa struktur umum arsip OBP memiliki dua register, yaitu register yang disusun oleh pegawai VOC di Batavia dan register yang disusun oleh pegawai VOC di kantor yang mengirimkan dokumendokumen ke Batavia. Struktur OBP lainnya dapat dilihat sebagai berikut: 


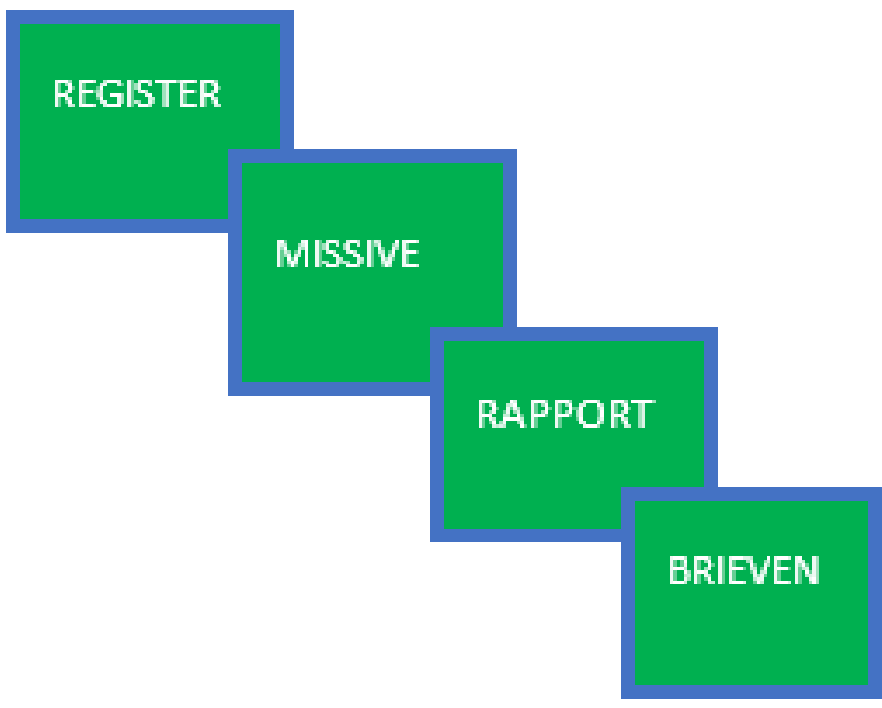

Gambar 4 Struktur lain arsip OBP

Arsip OBP diberi halaman di pojok kanan atas dan berkorespondensi dengan registernya. Artinya, ketika petinggi VOC di Batavia ingin melihat salah satu masalah, ia hanya tinggal melihat register untuk mengetahui ada di halaman berapakah masalah tersebut. Halaman terakhir pada setiap bundel menunjukan tempat di mana bundel tersebut disusun, seperti tampak pada gambar berikut:

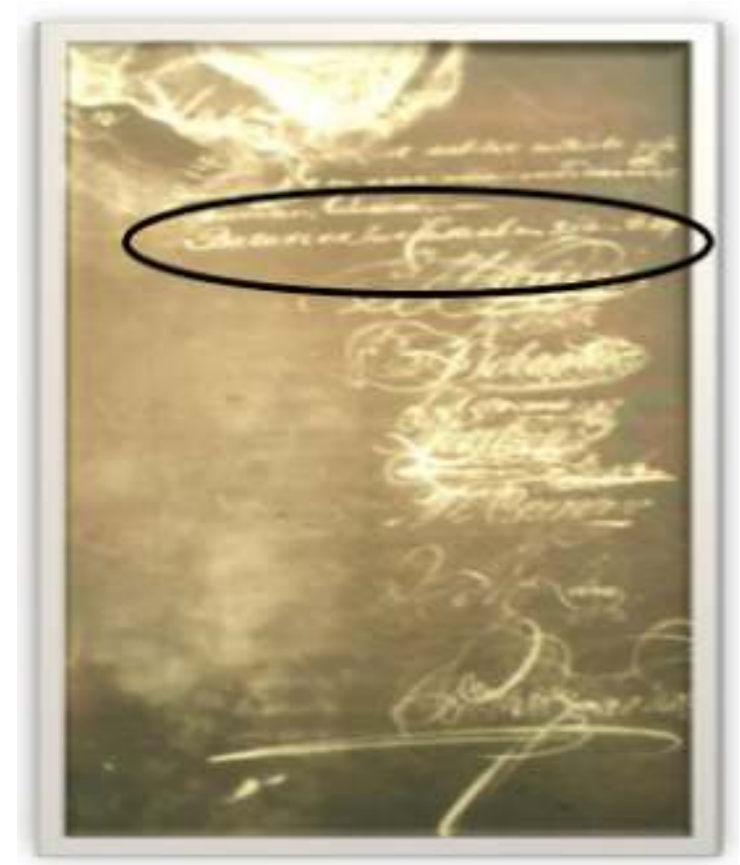

Gambar 5 Halaman terakhir bundel nomor 2381 
Bagian yang dilingkari menunjukkan tempat dokumen disusun:

"Batavia in het casteel den 5 febr Anni 1737”'

"Batavia di dalam Kastil, 5 Februari 1737"

Satu halaman sebelumnya tertulis:

"Wij ondergeschrevenen verklaaren deeze voorenstaande brieven ende de daar toegehoren [... unreadable...] desselve minute [...unreadable...] en daer mede over [ ...unreadable...] bevonden te hebben"

"Kami, yang bertanda tangan di bawah ini menerangkan surat berikut dan yang terkait [tidak terbaca] serta drafnya [tidak terbaca] yang ada di sini"

Halaman terakhir dari bundel lainnya juga ikut diteliti sehingga tulisan yang tidak terbaca dapat dibandingkan dengan yang ada di bundel lain. Misalnya yang ada di arsip nomor 2345:

"Wij onderges. verklaaren dese voorstaande brieven en daar toegehoorende bijlagen behoorlijk tegens derselve minute geconfronteert en $d a$ a r m e e d e accordeerende bevonden tehebben

Batavia den 6 april anno 1735"

"Kami, yang bertanda tangan di bawah ini, menerangkan bahwa suratsurat berikut dan lampirannya, ditempatkan bersama drafnya dan kami menyetujuinya

Batavia, 6 April tahun $1735 "$

Jadi, dari contoh di atas menjadi lebih jelas bahwa dokumen-dokumen itu disusun oleh pegawai di Batavia. Dari Batavia, dokumen lalu dikirim ke Amsterdam. Jika dilihat dari tanggal dokumen yang ditandatangani, maka bundel nomor 2381 dikirim di bulan yang sama, Februari 1737. Di tahun ini, kapal yang berangkat dari Batavia berjumlah 22, dan di Bulan Februari ada 6 kapal yang berangkat. Dari enam kapal tersebut, hanya satu yang sampai di Batavia, yaitu Papenburg. Kapal tersebut berangkat tanggal 6 Februari 1737 dan tiba di Belanda tanggal 23 Agustus 1737, hampir tujuh bulan berada dalam perjalanan. 
Tipe Dokumen di Bundel Arsip No. 2381

Bundel 2381 yang termasuk OBP, memuat banyak dokumen yang diterima di Batavia. Dokumen berisi informasi, data konsisten dalam berbagai media. Proses komunikasi melalu berbagai media ini disebut information supply. Definisi lain dari dokumen menyebutkan bahwa ia adalah kertas atau sekelompok kertas yang mengandung informasi di dalamnya, baik tertulis ataupun tercetak. Jadi, dokumen mengandung informasi.

Dari bundel arsip nomor 2381, ada beberapa tipe dokumen yang digunakan oleh pegawai VOC di Makasar untuk mengirim informasi ke pemerintahan di Batavia. Tipe dokumen tersebut sebagai berikut:

Tabel 1. Tipe dokumen di bundel arsip nomor 2381

\begin{tabular}{|l|c|}
\hline Tipe Dokumen & $\begin{array}{c}\text { Jumlah (dalam } \\
\text { satuan bundel) }\end{array}$ \\
\hline Brieven (Surat) & 17 \\
\hline $\begin{array}{l}\text { Dagregister (Catatan } \\
\text { Harian) }\end{array}$ & 1 \\
\hline Eisen (Permintaan) & 1 \\
\hline Instructie (Instruksi) & 4 \\
\hline Missive (Surat Dinas) & 10 \\
\hline Rapport (Laporan) & 4 \\
\hline $\begin{array}{l}\text { Register der Papieren } \\
\text { (Daftar Dokumen) }\end{array}$ & 2 \\
\hline $\begin{array}{l}\text { Verklaring } \\
\text { (Penjelasan) }\end{array}$ & 1 \\
\hline
\end{tabular}


Tabel 1 menunjukkan bahwa surat menjadi tipe dokumen yang paling banyak dikirim. Selanjutnya diikuti Laporan, Surat Dinas, Daftar Dokumen, Penjelasan, Catatan Harian, Permintaan, dan Instruksi. Setiap dokumen tersebut memiliki fungsi masing-masing, sehingga mereka memiliki bentuk editorial atau bentuk redaksinya. Bentuk redaksi ini menunjukkan bagaimana identifikasi formal dan konten dokumen disusun.

Arsip OBP nomor 2381 memiliki register yang dapat ditemukan di halaman pertama. Ada empat register yang memberikan gambaran isi bundel tersebut. Register pertama dibuat oleh pegawai di Batavia. Mereka menyusunnya setelah menerima dokumen dari Makasar:

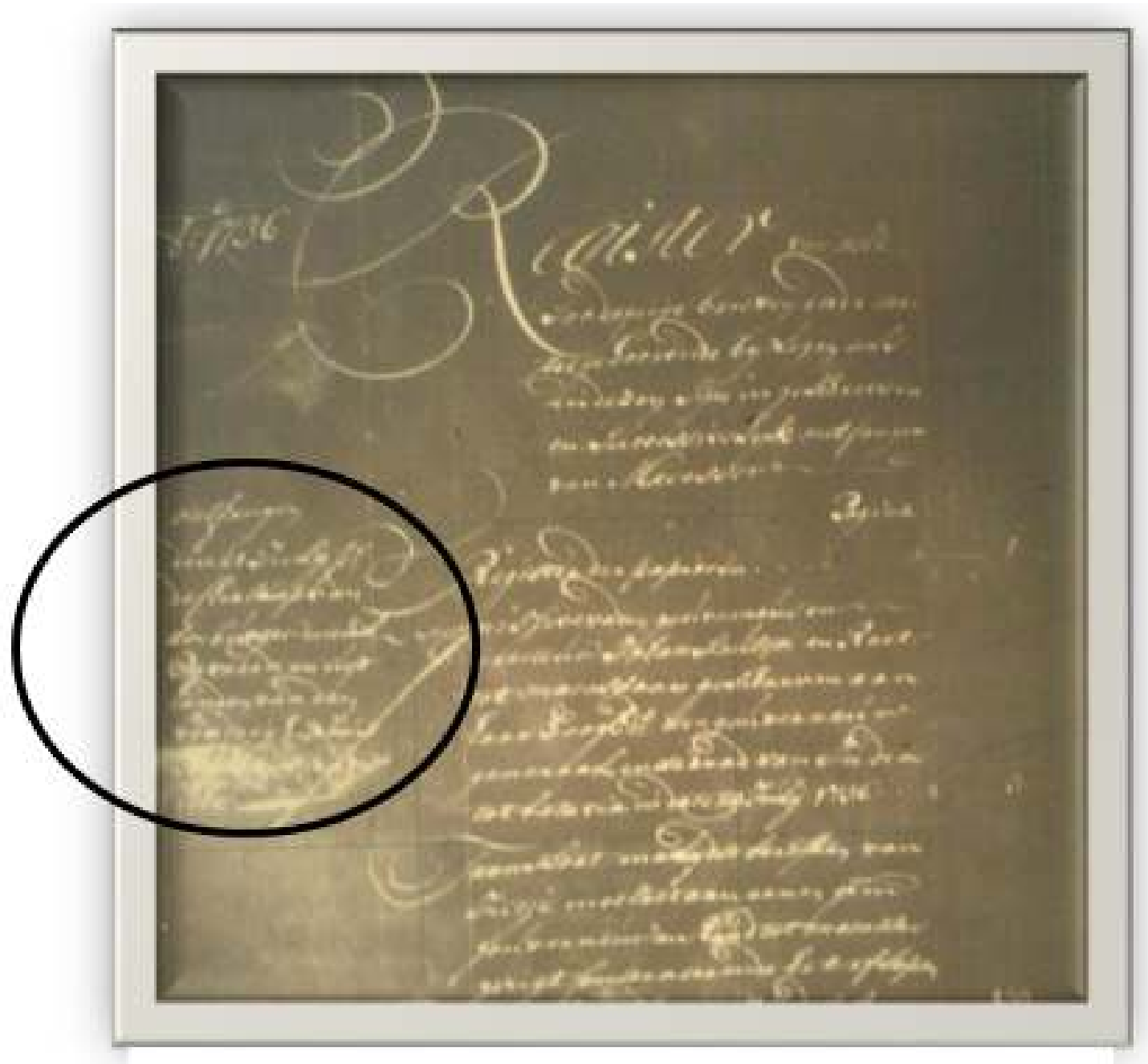

Gambar 6 Marjinalia di register arsip nomor 2381 
Bagian yang dilingkari adalah marjinalia yang berisi keterangan tanggal dokumen diterima. Marjinalia ini biasanya ditemukan di sebelah kiri atau kanan dokumen.

Setelah register, urutan tipe dokumen yang ditemukan adalah missive. Tipe ini berfungsi sebagai pengumuman ke pihak ketiga, dan juga berfungsi sebagai bukti. Missive sifatnya lebih formal dan digunakan untuk masalah-masalah resmi. Dalam bundel ini, ditemukan missive yang mengandung informasi umum tentang situasi di Makasar. Kemudian, instructie disusun setelah missive. Tipe dokumen ini berisi deskripsi tugas untuk seorang pegawai atau fungsionaris untuk melaksanakan fungsi mereka atau memberikan perintah dalam situasi tertentu. Tujuan dari instructie adalah untuk memberikan perintah dengan sengaja kepada seseorang atau lembaga secara sah menurut hukum.

Selanjutnya, rapport disusun setelah instructie. Rapport berfungsi sama dengan missive dan biasanya berkaitan dengan catatan atau jurnal resmi. Terkadang, rapport ditulis sebagai relaas. Brieven disusun setelah rapport. Tipe dokumen inilah yang digunakan untuk meneliti pertukaran informasi antara pemerintah di Makasar dan pegawai
VOC di kantor terluar. Surat-surat tersebut memuat banyak surat berbeda dari tempat berbeda. Mereka adalah aankomende en ingaande briven van en na de subaltern comptoirs (suratsurat masuk dan surat keluar dari dan ke kantor terluar), surat dari orang pribadi ke gubernur di Makasar, dan terjemahan surat dari penguasa lokal. Surat juga berfungsi sebagai pengumuman ke pihak ketiga, dan juga sebagai bukti. Contoh petikan surat berikut dari bundel nomor 2381: "aan alsvoren dese dient ten geleijden van een posthouder van de noorden provinsie die alle alhier op de chialoup sijn komen vlugten met seggen als dat het heele land over is dat uw edelens agtbaren raden door brengen deses ondervraagt. Wij hebben de brief van uw edeles agtbaren per heijtje Dolo ontfangen van den gedaage ons om onse bref ten dese magt uw edelens agtbare gesonden met versoek om per eerste schip te erlangen haarmede verblijve met haast / onderstond/ edelens / agtbare: heerens 
aldaar onderdanigste en trouw schuldige dienaar / was getekent / Thomas Vromans. Phillipus Barnewal en Hans Raads / in margine / in de rievier dan de mont der 30 julij 1736 ” (NL-HaNA, VOC, 1.04.02, inv.nr. 2381, p. 1317)

“K e p a d a y a n g sebelumnya

Dari penanggung jawab pos di sebelah utara provinsi yang datang dengan perahu yang atas dengan kuasa yang mulia surat ini sampai. Kami telah menerima surat yang mulia dengan perahu Dolo, yang menyuruh kami untuk segera menerima kapal/ kami dapat mengerti/ yang mulia dan yang terpercaya di sana/ ditandatangai/Thomas Vromans. Phillipus Barnewal dan Hans Raads/di marjin kiri/ di sungai pada tanggal 30 Juli 1736"

Dari contoh di atas, dapat dilihat fungsi dari surat sebagai pengumuman, sebagai notifikasi ke atasan dari bawahan sebuah organisasi. Surat tersebut juga berfungsi untuk menyampaikan informasi kepada yang menerima.

Tipe dokumen eisen atau permintaan, berfungsi sama dengan tipe verzoek. Tipe ini digunakan untuk memohon permintaan kepada seseorang atau organisasi. Setelah eisen, disusun tipe verklaring yang berfungsi sebagai penjelasan atas suatu masalah. Tipe terakhir adalah dagregister. Tipe ini berfungsi sebagai catatan harian sebagai bukti aktivitas sehari-hari. Dagregister disusun berdasarkan kronologis tanggal. Di bundel arsip nomor 2381, dagregister dari tanggal 2 Juli 1735 sampai akhir September 1736.

\section{Alur Informasi di Sulawesi 1735- 1737}

Makasar sebagai pusat administrasi di Sulawesi banyak menerima surat dari kantor-kantor terluar, Dalam kurun waktu tahun 1735-1737, surat yang datang mencapai 329 buah yang berasal dari kantor terluar ke Makasar dan sebaliknya. Korespondensi terbanyak, terjadi dari Maros ke Makasar dan sebaliknya. Jumlah surat dapat dilihat pada tabel berikut: 
Tabel 2. Jumlah surat yang berkorespondensi dengan Makasar

\begin{tabular}{|l|r|}
\hline \multicolumn{1}{|c|}{ Tempat } & Jumlah \\
\hline Maros & 50 \\
\hline Buton & 24 \\
\hline Bulukumba & 21 \\
\hline Tanakeke & 15 \\
\hline $\begin{array}{l}\text { Tempat } \\
\text { lainnya }\end{array}$ & 15 \\
\hline Bantimurung & 13 \\
\hline Bima & 11 \\
\hline Selayar & 7 \\
\hline Panakkukang & 6 \\
\hline Bone & 5 \\
\hline
\end{tabular}

Surat-surat di atas saling bertukar, dan terjadi pertukaran informasi. Pengirim surat bisa dari pegawai di kantor terluar seperti pedagang senior (oppercoopman) atau dari gubernur atau direktur di beberapa tempat tertentu. Terkadang, surat yang diterima di Makasar berasal dari petugas yang sedang berdinas di suatu tempat. Contohnya, ada surat yang berasal dari perahu, ditulis ketika pegawai VOC menghadapi para perompak. Pos-pos terluar seperti Maros dan Bantimurung memiliki seorang sersan yang ditempatkan secara permanen. Penempatan ini memudahkan peneliti untuk melacak pengirim suratnya.

\section{Tema Pertukaran Informasi di} Sulawesi 1735-1737

Dalam setiap surat yang dikirim ke
Makasar, para pengirim menceritakan secara umum kondisi pos-pos yang mereka tempati. Pada umumnya, pertukaran informasi yang terjadi di organisasi VOC adalah mengenai militair (militer), oorlog (perang), handel (perdagangan), diplomatie (diplomasi), medica (urusan kesehatan), scheepvaartbeweging (pergerakan kapal), dan VOC personnel (pegawai VOC). Namun pada kenyataannya, topik-topik tersebut bisa berkembang seperti yang ada di bundel arsip nomor 2381 dan tampak dalam tabel berikut:

Tabel 3. Topik pertukaran informasi di Sulawesi 1735-1737

\begin{tabular}{|l|r|}
\hline \multicolumn{1}{|c|}{ Topik } & Jumlah \\
\hline Roverij (Bajak Laut) & 52 \\
\hline Diplomatie (Diplomasi) & 41 \\
\hline VOC Personeel (Pegawai VOC) & 40 \\
\hline Militair (Militer) & 33 \\
\hline Opstand (Pemberontakan) & 27 \\
\hline Provisie (Persediaan Makan dan & \\
Barang) & 21 \\
\hline Financien (Keuangan) & 18 \\
\hline Others (Yang lainnya) & 18 \\
\hline Vaartuigen (Pelayaran) & 13 \\
\hline Cultuur (Perkebunan) & 12 \\
\hline Oorlog (Perang) & 12 \\
\hline Handel (Perdagangan) & 11 \\
\hline
\end{tabular}


Topik yang paling sering didiskusikan adalah mengenai bajak laut. Namun, apabila dilihat dari pengirimnya, yaitu dari Maros, topik yang paling banyak adalah mengenai diplomasi. Topik bajak laut menjadi bahasan paling banyak karena posisi Makasar sebagai kunci Nusantara di timur. VOC menggunakan Makasar sebagai kantor untuk mencegah penyelundupanpenyelundupan besar. Kapal-kapal yang ingin ke Makasar dari pos-pos terluar di Sulawesi harus melewati lautan yang arusnya ganas, juga ditempati oleh kebanyakan perompak laut. Jadi, bahasan mengenai bajak laut lebih mendominasi daripada perdagangan.

\section{Aktor Pertukaran Informasi di Sulawesi 1735-1737}

Dokumen yang diterima dari pos-pos terluar di Sulawesi diterima terlebih dahulu oleh pegawai VOC di Makasar dan juga diseleksi terlebih dahulu sebelum mereka mengirimkannya ke Batavia. Terdapat perbedaan dari register pada bundel nomor 2381 dibandingkan dengan register yang dibuat oleh pegawai VOC di Makasar. Ada beberapa dokumen yang tidak muncul di register yang dibuat oleh pegawai di Batavia. Kemungkinan, pegawai VOC di Batavia menyeleksi kembali dokumen yang masuk dari
Makas ar sebelum mereka mengirimnya ke Amsterdam.

Aktor pertukaran informasi melibatkan berbagai level di organisasi VOC, dari Gubernur dan Direktur Sulawesi ke berghopman (pegawai militer VOC yang bertanggung jawab di daerah pegunungan). Penguasa lokal juga menjadi penyedia informasi kepada petinggi VOC. Sebagai ilustrasi, Gubernur dan Direktur di Sulawesi menjadi orang pertama yang dituju. Merekalah yang banyak menerima informasi dari kantor-kantor terluar. Mereka kemudian membalas surat yang isi balasannya mengenai keputusan yang telah dibuat. Surat berikut adalah contoh surat yang ditulis oleh pemerintahan di Makasar kepada pegawai VOC di Bulukumba:

Boelecomba

\section{Aan den zergeant Jan Rosing}

Commandant en boekhouder Jan Scheepsdorp ten adsistentie 's comps wege aldaar

manhafte vrome

ten rescriptie op uwe brieven in datis 8 november en 21 junus ons successive alhier aangebragt zullen wij noteren dat wij met leedweesen gesien hebben 
dat door $u$ edele inde land streecke van uw schrijvers in datum 30 den jongst affgewerken en 14 van dese maand eerst geciteerde ons gee $n$ slaffe to $t$ rescribeereen gevende zullen wij op den laasten noteeren dat onder het op en toesigt van den a castij bescheijde comps surgen Christoffel alhier zijn gereverteerdde bij uw tot versterkinge gedient hebbende manschappen ander hun volle gesien Wijders hebben wij met verwonderingen en ons genoegen gesien dat 4 berg comingies sig souden hebben verstont o $m$ tegens ons $m$ e e $m$ ar $m$ a a $l s$ gerepeteerde ordres den petolanten puins bontolancas te willen adsisteeren met een troup van 3000 met schild en affegaij gewapende bergvolkeren, wij landeeren dat uw boven gementioneerde en buijten de paalen van hunnen pligt gewekene conningjes aan de post hebt ontbooden, om te onderstaan aff door haar lieden op gem. hulp waarlijk beloofd is wij willen dit ondersoek aan uwe vigilantie en inen gedefereert laaten en $i n t u s s$ e $n u w$ recommenderen dat bij aldien uw bevind dat desen stap door de coningen is gedaan sulx te ontveijiesen en meer $m$ e $n t i o n$ e e r d e bergcomingis onder dese aff geene respecteren herwaarts te depecheren dog bij onwilligheijd zult wij met de volkeren vande vlacktens dese disabedientie sraken doen opvatten en gevankelijk herwaards senden en bij te weerstelling $u w$ van het regt den natuur bedienen om also dese overtreedens van onse beveelen na exigentie loon na werken te doen en langen

Ik blijf / onderstond/ wel goeden vriend/was getekend/Johan Sautijn/ in marginel

Macasser IN het casteel Rotterdam den 17 December 1735 / daar onderstond/ B/; S/ onder 
den berger deses bekomt wederomte u over den /.../ soldaat Cornelis Snoek om alsvoren a casti sijnen dienst te proesteren (NLHaNA, VOC, inv.nmr. 2381,p. 1445)

Yang dicetak tebal adalah penerima dan pengirim surat. Pengirim surat tersebut adalah Johan Sautijn, Gubernur Sulawesi ketika itu, dan ditujukan kepada komandan dan akuntan di Bulukumba. Surat tersebut ditulis tanggal 17 Desember 1735 sebagai balasan dari surat tanggal 21 Juni, dan juga di bulan Oktober. Balasan surat memakan waktu lebih lama karena harus didiskusikan terlebih dahulu dengan Dewan, serta ketika pengirimannya bisa memakan waktu sekitar tiga sampai dua puluh hari menggunakan kapal atau perahu. Nantinya, dari Makasar, surat tersebut dengan dokumen lainnya dikirim ke Batavia, dan selanjutnya dikirim ke Belanda. Alur berikut menjelaskan bagaimana dokumen ini nantinya sampai ke Belanda:
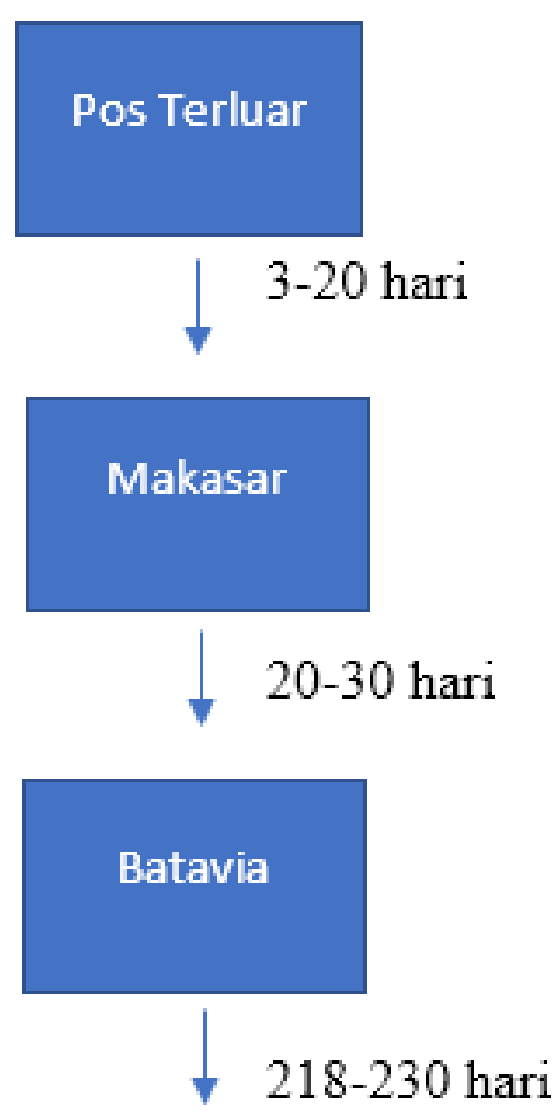

Amsterdam

Gambar 7 Diagram perjalanan dokumen dari pos terluar hingga Amsterdam

Aktor pertukaran informasi juga berasal dari coopman (pedagang), sergeant (sersan), gubernur dan direktur di luar Sulawesi, gezaghebber op schepen (otoritas di kapal), bookhouder (pemgenag buku), vendrig (letnan muda), dan commandant (komandan). Aktor juga bisa berasal dari penguasa lokal, seperti contoh berikut:

Translaat Maleijdse Brieff, 
gese door den coning in grooten van Bouton Aan den E E Agtbaren Heer Johan Sautijn gouverneur en directeur nevens den raad tot Macassar na meenigvuldige groet en compliment fond den Sulthan Sackioedin, en alle rijxgroote van Bouton aan den heer gouverneur en Raad tot Macassar zijn hoogheijts gesant mantrij milij $n e v e n s \quad t w e e$ pangelafsangt en een tolk tot bekent making de verlegenheijt van den Koning en groten wegens het versoek van den heer gouverneur over de stucken kanon die op zijn hoogheijts stranden onder water leggen op de plaats genaamt Lapando waar over den Koning en zijne groter 't haar gedagten hebben laten gaan dert zullen nooijt volgens ha ar geheugennisse sedert den tijd van den heer admiraal fiscaelen in usantie is geweest waar in tegendeel wanneer een schip off chialoup van de comp. op de stranden van Bouton is verongelukt en daar eenig geweest door zijn hoogheijts onderdanen van bekomen werd zoo laat de comp: deselve voor het rijk van Bouton verblijven en niet overgegeven dan de gesalveerde manschap alleen zoo als de bootouders verklaren ten tijde wanneer Crain Bouto Marans het land Bouton quam invaderen en te dies tijd door compagnies geweeren van dien rebel verlost geworden daar zij anders de nederlaag van hem zoude gekregen hebben waardoor den coning en grooten sistoneert dat de overgaaff van geweest tot nadeel en vertegentheijt voor zijn hoogheijts land en volk soude streeken te meet de comp: met den Coning in goede harmonie continueert.

Waardoor den Coning voortsz mantrij Milij tot den heer gouverneur affsent om zijn hoogheijts persoon te representeren 
en met zijn edele over het voorenstaande te besoigneeren en ingevalle die eenige misslagen door mogt begaan dat den heer gouverneur het niet ten $q u$ a a d ste $n$ z al duijdenVoorts laat den Coning in geselschap van voortsz mantrij tot den heer gouverneur overkomen den sergeant Pieter Gale rovers twee soldaten die de visite op de eijlanden van Bouton na onder gewoonte hebben gedaan.

Wijders verzoekt zijn hooght aan den heer gouverneur dat de recognitie penn. aan voorn. mantrij werden tot hand gestelt, alsmede dat aan sijn hoogheijt agent a costi een Rtting met des compagnies merk zal werden vereert om daardoor kenbaar te sijn.-

(onderstont) gesz tot Bouton in het koninklijk paleijs den 14 van de maand rabiulachier op vrijdag in het jaar 1148. ( N L- H a N A, V OC, inv.nmr. 2381, p. 554-56)

Surat di atas ditulis oleh Raja di Buton dan dialamatkan kepada pemerintahan VOC di Makasar. Surat tersebut telah diterjemahkan ke dalam bahasa Belanda oleh pegawai VOC di Makasar. Aktor pertukaran informasi yang berasal dari penguasa lokal biasanya adalah raja di beberapa wilayah. Ada juga surat dari penguasa lokal yang tidak disebut pangkatnya, seperti contoh surat berikut:

"Translaat Maleijtse brief gesz. Door Intje Ismael aan den edele agtbaren Johan Sautijn gouverneur en

directeur (unreadable) Macasser ..." (NL-HaNA, VOC, inv.nmr. 2381, p. 1201)

Intje Ismael disebut sebagai pengirim, namun tidak disebutkan ia berposisi sebagai apa.

\section{Kesimpulan}

Fungsi OBP adalah sebagai penghubung vital sistem komunikasi VOC yang menghubungkan organisasi VOC di Asia dan organisasi VOC di Belanda. Dalam kurun waktu tahun 1735-1737, sistem jaringan VOC di Sulawesi dapat berlangsung dengan lancar karena adanya korespondensi antara pemerintahan di pusat administrasi Makasar dengan pos-pos terluar. Pegawai-pegawai 
VOC di pos terluar dan penguasa lokal menjadi penyedia informasi bagi pemerintahan VOC di Makasar. Mengingat posisi Batavia sebagai pusat administrasi VOC di Asia, maka kantor di Makasar harus mengirimkan laporan ke Pemerintahan Agung di Batavia. Informasi yang diterima oleh pemerintahan VOC di Makasar akan digunakan sebagai bahan mentah untuk menyusun laporan ke Batavia. Laporan-laporan ini dikirim melalui kapal atau perahu. Aktor yang terlibat dalam pertukaran informasi adalah para pegawai VOC dari pangkat terendah hingga pangkat tertinggi, serta penguasa lokal.

Enam belas persen (16\%) surat-surat yang berkorespondensi antara pemerintahan Makasar dengan pos-pos terluar berisi informasi mengenai bajak laut, 15\% mengenai diplomasi, dan $12 \%$ memuat informasi mengenai pegawai VOC dan urusan militer. Maros menjadi pos terluar yang paling banyak berkorespondensi dengan Makasar, total mencapai 30\% dari jumlah surat. Rantai komunikasi berlanjut dari Makasar ke Batavia. Pegawai VOC di Batavia menyusun dokumen yang datang dari Makasar dan mengirimkannya ke kamar-kamar VOC di Belanda. Dokumen ini akan diangkut melalui kapal-kapal yang akan berangkat ke Belanda. Terakhir, analisis lebih lanjut mengenai pertukaran informasi dan juga koneksi komunikasi antara organisasi VOC yang paling kecil (pos-pos terluar) dengan yang lebih besar (Tuan-Tuan XVII di Belanda) menarik untuk diteliti.

\section{DAFTAR PUSTAKA}

\section{Sumber Primer}

\section{Arsip}

NL-HaNA, VOC, 1.04.04, inv.nr. 1481, 1481, 1496, 1623, 2345, dan 2381

Naskah Sumber

Dam, Pieter van. 1927. Beschryvinge van de Oostindische Compagnie. 's Gravenhage: Martinus Nijhoff.

Valentijn, Francois. 1724-26. Oud en Nieuw Oost-Indiën vervattende een naaukeurige en uitvoerige verhandelinge van Nederlands mogentheyd in die gewesten. Doordrecht en Amsterdam: Joannes van Braam en Gerard Onder der Linden.

\section{Sumber Sekunder}

Anonymous. 2000. VOC Glossarium, verklaringen van termen, verzameld uit de Rijks Geschiedkundige Publicatien die betrekking hebben op de Verenigde Oost-Indische Compagnie. Den Haag: Instituut voor de Nederlandse Geschiedenis.

Balk, L., and F van Dijk. 2007. Inventaris van het archief van 
de Gouverneur-Generaal en Raden van Indië (Hoge Regering) van de Verenigde Oostindische Compagnie en Taakopvolgers, 1612-1812. Jakarta - The Hague: Arsip Nasional Republik Indonesia and Nationaal Archief.

Broeders, Dennis, et al. 2011. De staat van informatie. Amsterdam: Amsterdam University Press.

Darnton, Robert. 2000. An early information society: news and the media in the eighteenth century Paris.

The American historical review 105 No.1 (2000): 1-35.

Gaastra, F.S. 2012. De geschiedenis van de VOC. Zuthpen: 11th edition: Walburg Pers.

Gaastra, F.S. 1989. Bewind en beleid bij de VOC: de financiële en commerciële politiek van de Bewindhebbers, 1672- 1702. Zuthpen: Walburg Pers.

Heijer, H. den. 2005. De geoctrooieerde compagnie: de VOC en de WIC als vorlopers van de naamloze vennootschap. Deventer: Kluwer.

Jacobs, Els. 2000. Koopman in Azië: de handel van de Verenigde Oost-Indische Compagnie tijdens de 18e eeuw. Zuthpen: Walburg Pers.

Jacobs, Els. 1991. Varen om peper en thee. Zuthpen: Walburg Pers.
Jeurgens, Charles., et al, eds. 2012. Colonial legacy in South East Asia: the Dutch Archives. 's Gravenhage: Stichting Archiefpublicaties.

Laidlaw, Z. 2005. Colonial connections 1815-1845: patronage, the information revolution and colonial government. Manchester: Manchester University Press.

Meilink-Roelofsz., et al. 1976. De VOC in Azië. Bussum: Unieboek b.v.

Meilink-Roelofsz., et al, eds. 1988. Dutch authors on Asian History: a selection of Dutch historiaography on the Verenigde Oostindische Compagnie.

Meilink-Roelofsz., et al. 1992. Inventaris van het archief van de Verenigde Oostindische Compagnie (VOC), 1602- 1795 (1811). Den Haag: Nationaal Archief.

Kooijmans, K. 1985. Bron en Publikatie: voordrachten en opstellen over de ontlsluiting van de geschiedskundige bronnen. 's Gravenhage: Bureau der Rijkscommissie voor Vaderlandse Geschiedenis.

Lequin, Frank. 2005. Het personeel van de Verenigde Oost-Indische Compagnie in Azië in de 18 e eeuw, meer in het bijzonder in de vestiging Bengalen. Alphen aan den Rijn: Canaletto / Repro-Holland. 
Smith, Woodruff D. 1984. The function of commercial centers in the modernization of European capitalism: Amsterdam as an information exchange in the seventeenth century. The journal of economic history 44 No.4: 985 1005.

Steensgaard, Niels. 1973. The Asian trade revolution of the seventeenth century. Chicago: The University of Chicago Press.

Sterkenburg, P.G.J van. 1981. Een glossarium van zeventiendeeeuws Nederlands. Groningen: Wolters- Noordhoff.

Soll, Jacob. 2009. The information master: Jean Baptiste Colbert's secret state intelligence system. Michigan: The University of Michigan Press / Ann Arbor.
Treuling, A.J.M. den. 2007. Archiefterminologie voor Nederland en Vlaanderen. 's Gravenhage: Stichting Archiefpublicaties.

Vriend, Nico. 2011. Het Informatiesysteem en netwerk van de VOC. Leiden: Unpublished master thesis.

Ward, Kerry. 2009. Networks of empire: forced migration in the Dutch East India Company. Cambridge: Cambridge University Press. 